\title{
Developing electronic teaching materials through comic mathematics media to increase student learning independence during the Covid-19 pandemic in Indonesia
}

\author{
*Rida Fironika Kusumadewi, Lecture, Universitas Islam Sultan Agung, Semarang, Indonesia and Doctoral \\ Student, Universitas Negeri Jakarta, Indonesia. ridafkd@unissula.ac.id \\ Amos Neolaka, Prof., Universitas Negeri Jakarta, Indonesia \\ Mahmuddin Yasin, Prof., Universitas Negeri Jakarta/Universitas Krisnadwipaya, Indonesia.
}

\begin{abstract}
This study aims to (1) obtain a product which is an electronic teaching material through valid mathematics comic media and (2) provide an appropriate description of the implementation of the use of teaching materials on the learning independence of elementary school students. This research method is Research and Development ( $R$ and $D$ ) which is carried out by adapting and combining the research and development of Borg and Gall and the Instructional Development Model (MPI). The stages in this development consist of preliminary studies, development, validation, testing, and implementation. The data collection technique uses an online questionnaire taking into account the conditions of the Covid19 pandemic. Based on the results of expert validation and field testing, this digital-based teaching material product is proven valid (material and graphic design) to be used in learning and is effective in increasing student learning independence. The teaching materials developed in this study are highly recommended to be used and utilized by students, teachers, and lecturers.
\end{abstract}

Keywords: teaching materials, electronics, mathematics, comic media, pandemics

Received: 03.11.2020

Accepted: 04.12.2020

Published: 05.01.2021

\section{INTRODUCTION}

In Indonesia, even all parts of the country are experiencing a coronavirus outbreak. It has been almost 10 months since the coronavirus outbreak has hit Indonesia. With this outbreak, the government has imposed WFH (work from home) which has an impact on society, of course also with the world of education (UNESCO, 2020). The government issued an education policy during a pandemic, namely learning is carried out through distance / online learning with parental guidance (Kemendikbud, 2020). Online learning is applied at several levels, from early childhood to college. Online learning, indirectly makes students in character building, namely the character of independence. Cultivating character is very appropriate for teachers to do during a pandemic (Kusumadewi et al., 2020). Student learning independence is influenced by learning trends in the current era, namely learning can be done where, when with whom, and through any learning sources (Al Aslamiyah et al., 2019). (Barker et al., 2005) the development of teaching materials used in various technologies is very important because it can prevent learning material that is left behind in its delivery.

Many factors become obstacles in the online learning process, especially in the facilities and infrastructure owned by students and teachers. Learning before the outbreak was carried out face-to-face and using conventional teaching materials or printed teaching materials so that changes in online learning made teachers more innovative in developing digital-based teaching materials so that the material presented could be well received by students. Research result (Sofyan et al., 2020), the need for development and improvement in appearance and practicality in a learning module such as an electronics module which has not been developed much. Electronic teaching materials are teaching materials that are included in the category of interactive teaching materials, this is due to the combination of text, images, and animation. (Jazuli et al., 2018). Judging from the definitions that have been expressed, electronic teaching materials include teaching materials that are categorized into teaching materials that are not projected and are technology-based teaching materials that can be operated on Android-based smartphones. Based on research results from (Alvitasari et al., 2016) that multimedia book electronic teaching materials can help students understand the material being taught. According to (Handayani, 2016), with advances in technology, mobile learning or M-Learning is one of the implementations of the modern learning process, because it is easy to access learning materials via smartphones. 
Another problem is the lack of electronic teaching materials that are designed according to the needs and characteristics of students. Providing information to students must adapt to student learning styles because it will affect what will be achieved (Sorensen, 2013). Another problem is the lack of electronic teaching materials that are designed according to the needs and characteristics of students. (Maufur \& Lisnawati, 2017) explaining the learning process will be easily accepted by students if the explanation of the material presented is accompanied by pictures. Through the arrangement of the dialogues contained in the picture, students will be assisted in understanding material at the same time being able to instill character values (Manalu Amin et al., 2017). Student learning independence can be seen if students have self-confidence, motivation, initiative, discipline, and responsibility (Pramana \& Dewi, 2014). Basically, independent learning is a concept where, from time to time, a student is empowered to learn on their own (Broad, 2006). Different from (Adman dkk, 2016) that students can be said to be independent if they can be responsible for what they do, learn without the help of others, learn based on their own will, and believe in their own choices. Independent learning will be appropriate as a learning technique if it is supported by the use of audiovisual instruments and technology (Kenneth, 2008).

Based on the underlying discussion of the problem, to increase character values, especially in the character of independent learning, it is necessary to learn using electronic teaching materials through mathematics comic media. Then the research problem can be formulated as follows: how to get electronic teaching materials through valid mathematics comic media during the pandemic, and how to increase student learning independence on the implementation of the use of electronic teaching materials through the media of mathematics comics during the Covid-19 pandemic.

\section{METHODS}

This study uses a development approach and method (Research and Development). The stage of developing electronic teaching materials through the media of mathematics comics was designed using Brog and Gall's research (Gall, M. D., Gall \& Borg, 2014) and the Instructional Development Model (MPI). Research using an R\&D approach aims to develop and validate educational outcomes and to discover new knowledge through basic research. This research is also intended to answer specific questions about practical problems through 'applied research' which is used to improve educational practice.

The results of the adaptation of teaching material development start from preliminary studies, development, validation, testing, and implementation of teaching materials. The teaching material design is developed into five steps. The first step is the teaching study stage, the second is the development of teaching materials, the third is a validation of the teaching materials by experts, the fourth is the trial of teaching materials, the fifth is the implementation of teaching materials. Preliminary studies in research are needed to conduct literature studies and field studies. (Rahma et al., 2017) a literature study is used to collect various information related to the development of electronic mathematics teaching materials. Meanwhile, field studies are carried out to obtain information about the needs needed to support learning activities.

The second stage in this research is at the stage of developing electronic teaching materials through the media of mathematics comics. At this stage, the researchers compile electronic teaching materials according to the needs analysis that has been obtained(Rufii, 2015) explained that the development plan is an outline of the contents of the module to be developed.

In general, many students complain about online learning. Online learning is no more interesting than face-to-face learning (Mulyanti et al., 2020). Supported by research results (Alsadoon, 2017) that the results of the questionnaire obtained, many students were not happy with online learning. The third stage is the validation of electronic mathematics teaching materials. This validation test is conducted by experts, to assess the feasibility of the developed electronic teaching materials. The team of experts from the validation test consisted of three experts in the field of graphic design. By validating the product to experts, it is continued with product analysis and revision based on suggestions for improvement. (Sofyan et al., 2020) Then the product is revised until it gets valid criteria from experts.

The fourth stage is testing the products that have been developed by assessing the appropriateness of teaching materials to users, namely teachers and students. By testing learning products to students, namely one student and 3 student trials, namely product analysis and revision based on one on one test results. The next trial was a small group trial of 20 students with product analysis and revisions based on the results of group trials.

The fifth stage is the stage of implementing electronic teaching materials. This stage is carried out to see the value of the character of students' learning independence after using the product that has been developed. At this stage, the researcher used the control group and the experimental group. And the second group took the pre-test and post-test. The pre-test in the experimental group was given to determine the 
learning independence of students before being treated using the product developed. Meanwhile, the posttest was conducted to measure the use of the products developed in this group. Meanwhile, the control group developed a pre-test before learning without using a product developed through a post-test at the end of the learning process.

The research was conducted using the research and development method so that the subject was involved in the teaching material design stage. The subjects of the validation of teaching materials were 3 learning design experts. The research data were collected through interviews and questionnaires. The results of the interviews analyzed were used as new teaching materials through the media of mathematics comics which were validated by three teams of experts namely graphic design experts. Meanwhile, the questionnaire was used to measure students' learning independence using a t-test and normalized gain test by looking at the results of the pre-test and post-test in the control class and the experimental class. The questionnaire developed in this study is a list of respondents who reveal the suitability of the content contained in each statement. The data technique in this study is to use an online approach questionnaire. This was done because the current research condition is still in the state of the COVID-19 pandemic in Indonesia.

\section{RESULTS}

This study aims to obtain a product which is an electronic teaching material through the media of valid mathematics comics and provides an appropriate description of the implementation of the use of teaching materials on the learning independence of elementary school students during the pandemic. After analyzing preliminary studies and field studies, teaching materials are needed to support the learning process during this pandemic. Teaching materials that are appropriate and in accordance with the needs of students are electronic teaching materials, where this teaching material can be accessed via a smartphone or android cellphone..

\section{Preliminary studies}

The preliminary study was conducted by means of interviews with teachers and students. The results of the interview process were then analyzed which were used as information material needed by researchers in developing products. The data needed in the interview process include knowing the availability and development process of teaching materials, second knowing the objective conditions of learning mathematics during the pandemic, third is the weakness of teaching materials that have been used during the learning process during the pandemic. The findings obtained based on the results of the interviews were that mathematics learning in high class became the basis for developing electronics teaching materials through the media of mathematics comics. The teaching materials developed are teaching materials that are in accordance with the characteristics of students, namely by displaying pictures when delivering the material, so that students can operate the teaching materials via smartphones or Android independently.

The results of the analysis obtained were that during the COVID-19 pandemic the learning process took place through group watshaps. Often teachers deliver material by giving orders to open student worksheets or printed books owned by students. The learning process is carried out by students independently because after students have read books from the teaching materials they have, students do practice questions on the student worksheets ordered by the teacher. This learning process continues during this pandemic. So that it makes students get bored quickly, in receiving learning.

From the results of the interview, it was found that the teacher found it difficult when delivering the material because the teacher did not have provisions in making material through electronics. Seen from the student's point of view, that students feel bored with monotonous learning during a pandemic, resulting in a decrease in the character value of students' learning independence.

The need for electronic teaching materials through mathematics comic media is indeed very important during the current pandemic. Because electricity teaching materials through the media of mathematics comics are an attractive and efficient choice to become teaching materials in today's times. The results of the above analyses show that teachers still use conventional teaching materials during a pandemic like this, resulting in a lack of motivation for students to accept the material. On the other hand, students want teaching materials that foster their learning independence in receiving learning. This is felt by students when students receive learning, students are often told by their parents to learn, besides that, students are not responsible for the assignments received, most students are still assisted by their parents in working on the questions given by the teacher. , because students learn without the will that grows from these students. 


\section{Teaching Material Development}

The second stage is the stage of developing teaching materials. At this stage, researchers began to design products based on the analysis of preliminary studies. The teaching materials developed are electronic teaching materials. This product development starts from: (1) writing down instructional goals; (2) formulating the material in detail; (3) create a measuring tool for success; (4) writing a media script which includes designing a panel layout (storyboard), designing a display, selecting characters, developing comic teaching materials.

The teaching material chosen is a cube space that is learned in grade V elementary school. Furthermore, instructional objectives are made after knowing basic competencies and expressed by operational verbs to measure the ability to understand mathematical concepts. Materi yang akan dikembangkan adalah bangun ruang kubus yang membahas tentang definisi bangun ruang kubus, luas permukaan kubus dan volume kubus. Selanjutnya, indikator dan tujuan pembelajaran pada materi dapat ditetapkan.

The measuring instrument used by researchers is multiple choice questions as a learning evaluation so that the purpose of the material presented can improve the ability to understand mathematical concepts. The practice questions on the material consist of seven questions and their discussion. In addition, there is a behavior checklist that functions to find out whether students have mastered or understood the material that has been studied.

Writing a media script, the first thing is the storyboard. The layout panel (storyboard) is the stage of making a dialogue design better known as a storyboard. Storyboard serves as a medium for conveying ideas or ideas to others in the form of images or text. The contents of this digital comic storyboard include cover, material title, preface, table of contents, character introduction, material, conclusion, practice questions, evaluation questions. Storyboards are made to simplify and speed up the process of making digital comic teaching materials and make it easier for people to use the electronic teaching materials that are presented.

Display design is one of the criteria in the first design development stage, namely the display design stage because the display is a priority to attract readers. Consists of several aspects of appearance such as color display, background display, font size display, font type, and so on. Making character designs includes physical appearance, personality, and required details. Consists of two main characters and one supporting character.

Recreating comics is the stage of starting comics into digital form using application software, namely Corel Draw and Photoshop. All matters relating to coloring, providing background, typesetting, and so on are done at this stage

The digitization stage is the stage of completing the creation of comics in the CorelDraw and Photoshop software applications, so the next step is the application of comics to the digitization stage based on Android. The comics will be arranged coherently with various menus according to the sections.
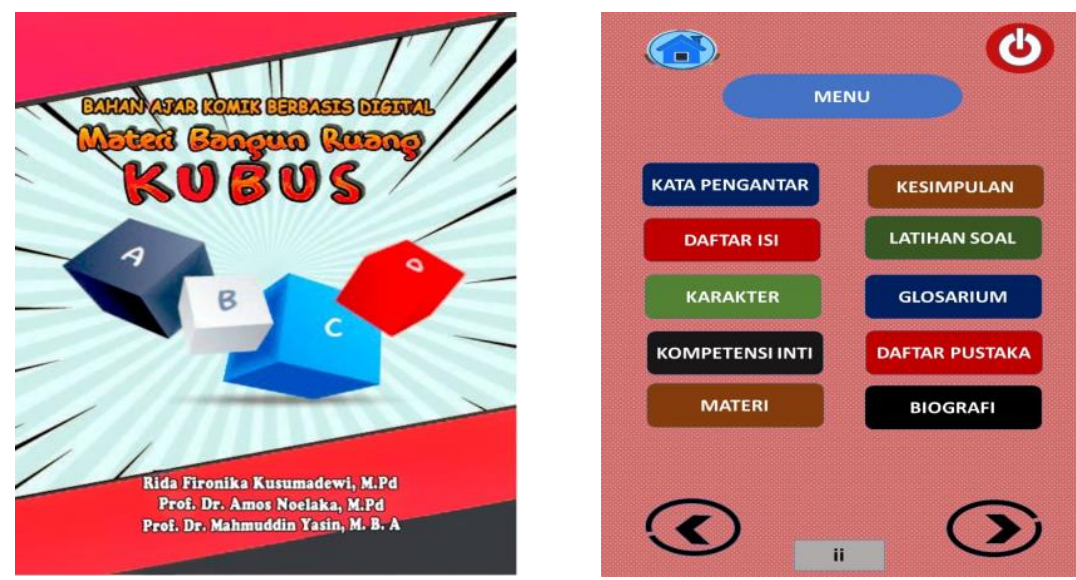

Figure 1. Cover and table of contents for electronic teaching materials through the media of mathematics comics 


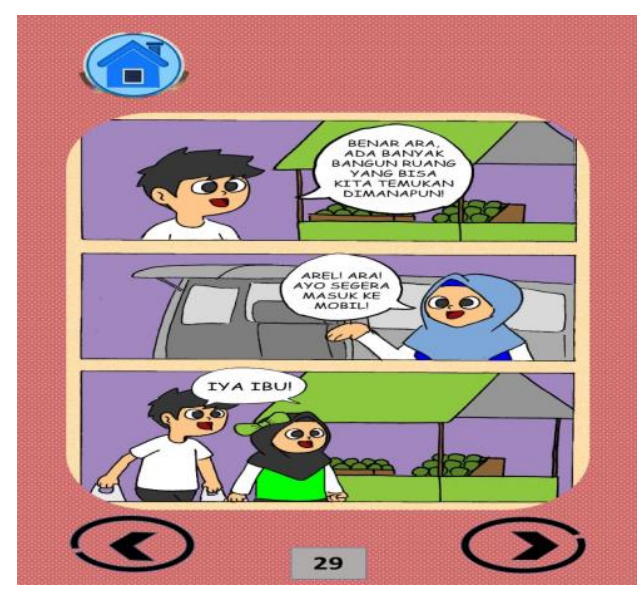

FIGURE 2. Display of material on developed teaching materials

\section{Validation of Teaching Materials}

Design Expert Validation is carried out by three people who are competent in the field of Design and Graphics. Graphic design validation data were analyzed using the Lawshe formula to determine the content validity ratio (CVR), which means the value of the content validity ratio was categorized as: (1) if the value of CVR $<0$ then the item was declared not good; (2) if the value of CVR $=0$ then the item is declared unfavorable; (3) if CVR $>0$ then the item is declared good. The results of the validation from the expert team can be seen in the table below:

Table 1. Hasil validasi tim ahli desain grafis.

\begin{tabular}{|c|r|c|c|c|c|}
\hline \multirow{3}{*}{ Aspect } & \multicolumn{5}{|c|}{ Graphic design } \\
\cline { 2 - 6 } & $\mathbf{M}$ & $\mathbf{C V R}$ & $\mathbf{1 / 2 M}$ & information & Conclusion \\
& & & & & \\
\hline A & 2,5714286 & 0,4286 & 1,5 & Good & VALID \\
\hline B & 3 & 0,4286 & 1,5 & Good & VALID \\
\hline Quantity & 2,7857143 & 0,4286 & 1,5 & Good & VALID \\
\hline
\end{tabular}

In table one, the results of the validation of three teams of graphic design experts show that aspect A, namely the layout or display design, gets a CVR value> 0 with valid criteria or is suitable for use, while in aspect $B$, namely the animated aspect CVR> $0=0.428$ with good criteria. So it can be concluded that the graphic design of the product being developed is suitable for use.

\section{Product Trial}

One-to-one trials are conducted after revising teaching materials from a number of due diligence series by experts with the aim of seeing the feasibility of the product from the user's point of view. The one-on-one trial assessment by students totaled 13 questions and the results of the analysis showed that each item was in a good category. While the one-on-one trial assessment by the teacher consisted of 33 questions and the results showed that each item had a good category. Overall, it does not provide input on the model product being developed, therefore all the elements assessed have been declared feasible from the point of view of the user.

Small group trials were conducted after the revision of the results of the one-by-one trials was completed, which also aimed to determine the feasibility of teaching material products developed by users. The assessment of small group trials by students consisted of 10 questions and the results of the analysis showed that each item was in a good category. While the one-on-one trial assessment by the teacher consists of 33 questions and the results of each item are in a good category. Overall it does not provide input on the teaching material products developed, therefore all the elements assessed have been declared feasible from the point of view of the user.

After the feasibility test of the user is carried out, the product being developed is ready for use. This product is used as an electronics teaching material through the media of mathematics comics to determine the increase in student learning independence. 


\section{Implementation}

The implementation stage of the teaching materials was carried out in grade V SDN Mukti Harjo Lord and SDN Gebang Sari 3 Semarang City. The goal is to measure and determine the effectiveness of the product users of teaching materials developed. This effectiveness is measured through a student learning independence questionnaire after participating in learning using products that have been developed. The independence measured in this research is the responsibility, learning without the help of others, based on their own will. The results of student learning independence can be seen in Table 2 below:

Table 2. The results of the t-test are the students' learning independence for the experimental class and the control class.

\begin{tabular}{|c|c|c|}
\hline information & Experiment & control \\
\hline quantity(n) & 58 & 54 \\
\hline Average & 8,913793103 & 3,724138 \\
\hline SD & 0,08015729 & 0,301887 \\
\hline Varians & 0,08015729 & 0,301887 \\
\hline${ }^{*}$ T.count & \multicolumn{2}{|c|}{744,3013957} \\
\hline *T.table & \multicolumn{2}{|c|}{1,981765282} \\
\hline
\end{tabular}

Based on table 2, the experimental class with a number of respondents 58 got an average value of 3.91 with a standard deviation of 0.08 and a variant of 0.08 , while the control class with a total of 54 respondents got an average value of 3.72 with a standard deviation by 0.30 . From the experimental and control data obtained, the t-count is 744.30 , and the t-table is 1.98 . It can be concluded from Table 2 that there are differences in learning independence between the control group and the experimental group on the use of teaching materials that have been developed. After knowing the results of the t-test, it is seen the increase in independence in the use of electronic teaching materials through the media of mathematics comics in the experimental group. The results of the average increase in student learning independence can be seen in the following table:

Table 3. The results of each aspect of independent learning

\begin{tabular}{|l|c|c|c|c|}
\hline \multirow{2}{*}{ Aspect } & \multicolumn{2}{|c|}{ Experiment Group } & \multicolumn{2}{c|}{ Control Group } \\
\cline { 2 - 5 } & Pretes & Post & Pretes & Post \\
\hline Responsible & 59 & 174 & 55 & 55 \\
\hline Learn without the help of others & 66 & 170 & 61 & 61 \\
\hline Learn on your own accord & 63 & 173 & 57 & 100 \\
\hline \multicolumn{1}{|c|}{ Quantity } & & & & \\
\hline \multicolumn{2}{|c|}{188} & 517 & 173 & 216 \\
\hline
\end{tabular}

Based on table 3, the results of the acquisition in the responsibility aspect of the experimental group obtained an increase in the score of 115 , while in the learning aspect without the help of others, the score increased by 104 and in the learning aspect according to one's own abilities obtained an increase in score of 110. In contrast to the control group where the pretest results before being given traditional teaching materials or printed teaching materials, the increase was not too significant. It is proven that in the aspect of responsibility and in the aspect of learning without the help of others there has been no increase at all, while in the aspect of learning according to one's own will it has increased by 43 .

Table 4. The results of the $N$-Gain calculation in the experimental and control classes

\begin{tabular}{|c|c|c|c|c|c|c|}
\hline \multirow{2}{*}{} & \multicolumn{3}{|c|}{ Eksperiment Group } & \multicolumn{3}{c|}{ Control Group } \\
\cline { 2 - 7 } & Pretest & Posttest & $\begin{array}{c}\text { \%Gain } \\
\text { Ternormalisasi }\end{array}$ & Pretest & Posttest & $\begin{array}{c}\text { \%Gain } \\
\text { Ternormalisasi }\end{array}$ \\
\hline N & 58 & 58 & 58 & 54 & 54 & 54 \\
\hline Mean & 3,24 & 8,91 & 6,43 & 2,98 & 3,72 & 0,70 \\
\hline criteria & \multicolumn{3}{|c|}{ Tinggi } \\
\hline
\end{tabular}


Based on table 4 the results of the calculation of $\mathrm{N}$-Gain in the experimental class were obtained with the number of respondents 58 , the average value on the pre-test or before treatment using electronic teaching materials was 3.24 while the post-test results obtained an average value of 8.91. So that the value of the $\mathrm{N}$-gain phase process was obtained of 6.43 with the criteria of high learning independence in the experimental group. In contrast, the control group had a low improvement criterion, namely the percentage of $\mathrm{N}$-Gain getting a score of 0.70 .

\section{DISCUSSION AND CONCLUSIONS}

The presence of the coronavirus has changed the learning tradition, a learning culture from home which makes teachers have to be more creative in designing learning, electronic-based teaching materials to support distance learning (Ambarita et al., 2020). Many students now have various types of technology such as the iPhone, Android, and iPad, tablets (Susilana, 2020). The technology that students currently have is very supportive of the acceptance of material to students through electronic teaching materials. In addition, there is an increase in student participation and cooperation during learning using cellular technology (Righi, 2012).

The ability to solve their own problems using their own ideas in terms of learning mathematics using digital media (Taleb et al., 2015). The development of digital comic learning media in thematic learning in elementary schools can motivate students in a learning process that is suitable for use in learning (Mustikasari et al., 2020). It is also emphasized in research (Jannah, Prasojo\&Jerusalem, 2020) In line with the times and technology, digital literacy needs special attention that must be developed by educators so that it can balance the tendencies of the characteristics possessed by students.

The learning process during a pandemic like this is more effective if the delivery of material uses electronic teaching materials that are designed according to current student characteristics so that students are able to learn independently at home. Learning media has a positive contribution to learning, namely by delivering messages (Skemp, 1962).

Products developed must go through expert tests that have been carried out by a team of graphic design experts. The assessment of the graphic design expert team aims to see the quality of the product in terms of images and graphics. Overall, there are several suggestions given by the expert team, namely adding audiovisuals and videos to the developed teaching materials.(Suyitno \& syakirun, 2018) The use of attractive audiovisuals as a learning medium can lead to independence for students. Supported by research results (Susilana, 2020), So far, many educators have given assignments independently to their students. This is proven based on the results of the study, that after students were given treatment using electronic teaching materials through the media of mathematics comics, the students' learning independence increased compared to students who were not given treatment through the products developed. It is proven in the experimental group that the increasing number of aspects of responsibility is 115.

The responsibility of students for learning is embedded in students. Students are on time in participating in the lesson, feel happy with the electronic teaching materials provided. The form of responsibility is the mental, emotional and physical involvement of students in responding to activities carried out in the learning process and supporting the achievement of goals, and being responsible for their involvement (Nursa'ban, 2013). Furthermore, after getting students to learn to use the products developed, students often learn not to be assisted by their parents, meaning that students have started to be independent in receiving learning, parents no longer ask their children to read material from the teaching materials they have. Until doing the exercises given by the teacher, students work based on their own abilities.

From the explanation above, it is stated that the results of the validation from a team of graphic design experts by 3 validators produce high scores and the teaching materials developed are suitable for use. Whereas the character values of student learning independence experienced a significant increase in the experimental group, meaning that electronic teaching materials through the media of mathematics comics were feasible to be used to increase student learning independence during the pandemic.

\section{REFERENCES}

Adman dkk. (2016). Peran kecerdasan emosional sebagai faktor yang mempengaruhi kemandirian belajar siswa ( The role of emotional intelligence as a factor in affecting student independence learning ). Pendidikan Manajemen Perkantoran, 1(1), 215-223.

Al Aslamiyah, T., Setyosari, P., \& Praherdhiono, H. (2019). Blended Learning Dan Kemandirian Belajar Mahasiswa Teknologi Pendidikan. Jurnal Kajian Teknologi Pendidikan, 2(2), 109-114. https://doi.org/10.17977/um038v2i22019p109 
Alsadoon, H. (2017). Students' perceptions of e-assessment at saudi electronic university. Turkish Online Journal of Educational Technology, 16(1), 147-153.

Alvitasari, D., Sudarisman, S. N., \& Irsadi, A. (2016). Unnes Journal of Biology Education. Journal of Biology Education, 5(2), 198-206.

Ambarita, J., Helwaun, H., \& Houten, L. Van. (2020). Workshop Pembuatan E-book Sebagai Bahan Ajar Elektronik Interaktif Untuk Guru Indonesia Secara Online di Tengah Covid 19. Community Engagement \& Emergence Journal, 2(1), 44-57.

Barker, A., Krull, G., \& Mallinson, B. (2005). A proposed theoretical model for m-learning adoption in developing countries. Proceedings of MLearn, 1-11.

Broad, J. (2006). Interpretations of independent learning in further education. Journal of Further and Higher Education, 30(2), 119-143. https://doi.org/10.1080/03098770600617521

Gall, M. D., Gall, J. P., \& Borg, W. R. (2014). Applying educational research: How to read, do, and use research to solve problems of practice. Pearson Higher Ed.

Handayani, R. D. (2016). Pengembangan Bahan Ajar Elektronik Berbasis Mobile-Learning Pada Mata Kuliah Optik Di Fkip Universitas Jember. Ta'dib, 17(1), 81. https://doi.org/10.31958/jt.v17i1.262

Jannah, M., Prasojo, L. D., \& Jerusalem, M. A. (2020). Elementary School Teachers' Perceptions of Digital Technology Based Learning in the 21st Century: Promoting Digital Technology as the Proponent Learning Tools. Al Ibtida: Jurnal Pendidikan Guru MI, 7(1), 1. https://doi.org/10.24235/al.ibtida.snj.v7i1.6088

Jazuli, M., Azizah, L. F., \& Meita, N. M. (2018). Pengembangan Bahan Ajar Elektronik Berbasis Android Sebagai Media Interaktif. LENSA (Lentera Sains): Jurnal Pendidikan IPA, 7(2), 47-65. https://doi.org/10.24929/lensa.v7i2.22

Kemendikbud. (2020). Panduan Penyelenggaraan Pembelajaran di Masa Pandemi COVID-19 (Vol. 1, Issue 1).

Kenneth, E. . (2008). Self-Directed Learning and Emotional Intelligence: Interrelationships Between the Two Constructs, Change and Problem Solving. International Journal of Self-Directed Learning, 5(2).

Kusumadewi, R. F., Yustiana, S., \& Nasihah, K. (2020). MENUMBUHKAN KEMANDIRIAN SISWA SELAMA PEMBELAJARAN DARING SEBAGAI DAMPAK COVID-19 DI SD. Jurnal Riset Pendidikan Dasar (JRPD), 1(1), 7-13.

Manalu Amin, M., Hartono, Y., \& Nyimas, A. (2017). Pengembangan Media Komik Matematika Berbasis Nilai Karakter pada Materi Trigonometri di Kelas X SMA Negeri 1 Indralaya Utara. Jurnal Elemen, 3(1), 35. https://doi.org/10.29408/jel.v3i1.305

Maufur, S., \& Lisnawati, S. (2017). Pengaruh Penggunaan Media Gambar Berseri Terhadap Keterampilan Berbicara Bahasa Indonesia Siswa Kelas III MI Al-Washliyah Perbutulan Kabupaten Cirebon. Al Ibtida: Jurnal Pendidikan Guru MI, 4(2), 189. https://doi.org/10.24235/al.ibtida.snj.v4i2.1888

Mulyanti, B., Purnama, W., \& Pawinanto, R. E. (2020). Distance learning in vocational high schools during the covid-19 pandemic in West Java province, Indonesia. Indonesian Journal of Science and Technology, 5(2).

Mustikasari, L., Priscylio, G., Hartati, T., \& Sopandi, W. (2020). The development of digital comic on ecosystem for thematic learning in elementary schools. Journal of Physics: Conference Series, 1469(1), 0-6. https://doi.org/10.1088/1742-6596/1469/1/012066

Nursa'ban, M. (2013). Peningkatan Sikap Tanggung Jawab Dan Kemandirian Belajar Mahasiswa Melalui Metode Tutorial Di Jurusan Pendidikan Geografi. Jurnal Cakrawala Pendidikan, 3(3), 432-443. https://doi.org/10.21831/cp.v3i3.1630

Pramana, W. D., \& Dewi, N. R. (2014). Pengembangan E-Book Ipa Terpadu Tema Suhu Dan Pengukuran Untuk Menumbuhkan Kemandirian Belajar Siswa. USEJ - Unnes Science Education Journal, 3(3). https://doi.org/10.15294/usej.v3i3.4267

Rahma, S. Z., Mulyani, S., \& Masyikuri, M. (2017). Pengembangan Modul Berbasis SETS (Science, Environment, Technology, Society) Terintegrasi Nilai Islam di SMAI Surabaya pada Materi Ikatan Kimia. Jurnal Pendidikan (Teori Dan Praktik), 2(1), 70. https://doi.org/10.26740/jp.v2n1.p70-76

Righi, R. (2012). The Impact of Laptop Computers on Student Learning Behaviors as Perceived by Classroom Teachers (Issue May). Toledo.

Rufii, R. (2015). Developing Module on Constructivist Learning Strategies to Promote Students' Independence and Performance. International Journal of Education, 7(1), 18. https://doi.org/10.5296/ije.v7i1.6675

Skemp, R. R. (1962). The Need for a Schematic Learning Theory. British Journal of Educational Psychology, 32(P2), 133-142.

Sofyan, H., Hartati, S., Anggereini, E., Muazzomi, N., \& Ramadhan, S. (2020). Developing e-module local wisdom based for learning at kindergarten in Jambi, Indonesia. Elementary Education Online, 19(4), 
2074-2085. https://doi.org/10.17051/ilkonline.2020.763331

Sorensen, E. (2013). Implementation and student perceptions of e-assessment in a Chemical Engineering module. European Journal of Engineering Education, 38(2), 172-185. https://doi.org/10.1080/03043797.2012.760533

Susilana, R. (2020). Students ' Perceptions toward Online Learning in Higher Education in Indonesia during COVID-19 Pandemic. Elementary Education Online, 19(4), 9-19. https://doi.org/10.17051/ilkonline.2020.04.101

Suyitno, S., \& syakirun, syakirun. (2018). Pengembangan Media Pembelajaran Audio Vidio Pada Motor Bakar 4 Langkah Untuk Meningkatkan Prestasi Belajar. Jurnal Pendidikan Surya Edukasi, 4(1), 19-34.

Taleb, Z., Ahmadi, A., \& Musavi, M. (2015). The Effect of M-learning on Mathematics Learning. Procedia Social and Behavioral Sciences, 171, 83-89. https://doi.org/10.1016/j.sbspro.2015.01.092

UNESCO. (2020). Education: From Disruption to Recovery. Retrieved November 15, 2020. 